\title{
Larval growth, silk production and economic traits of Bombyx mori under the influence of honey-enriched mulberry diet
}

\author{
N. Thulasi and S. Sivaprasad* \\ Department of Zoology, Smt. N.P.S. Government College for Women, Chittoor- 517001 (A.P.), INDIA \\ *Corresponding author. E-mail: sivaprasadzoology@gmail.com \\ Received: November 13, 2014; Revised received: January 24, 2015; Accepted: April 18, 2015
}

\begin{abstract}
The impact of honey on the silkworm, Bombyx mori was demonstrated with reference to the larval growth, silk gland proteins and economic parameters of sericulture. The honey works well at a concentration of $2 \%$ in distilled water. At this concentration it promotes growth rates in the silkworm larvae during fifth instar development. It positively reinforces the day-to-day larval growth rate by 4.75 additional percentile points, silk gland growth rate by 4.45 additional percentile points and the gland-body ratio by additional 6.64 percentile points. It stimulates silk protein synthesis in all the three segments of the silk gland, viz., the anterior, middle and posterior parts. Under its influence, the silk gland protein profiles grew significantly by 14.85 additional percentile points in the anterior silk gland (ASG), minimally by 8.68 additional percentile points in the middle silk gland (MSG) and maximally by 15.17 additional percentile points in the posterior silk gland (MSG), compared to their control values. It also stimulates the core shell protein synthesis by $18 \%$ and retards floss protein synthesis by $\sim 25 \%$ in the three segments of silk gland. In doing so, it contributes to sericulture industry by causing im-provements in profit making economic traits such as gland-body ratio, cocoon weight, shell weight, raw silk weight, denier and renditta and by reducing the production of floss, which contributes to loss in the sericulture industry. Honey is suggested as a profitable supplementary diet for silkworm.
\end{abstract}

Keywords: Bombyx mori, Larval growth, Honey, Silk proteins, Economic traits

\section{INTRODUCTION}

The impact studies of exogenous nutrients on the growth, metabolism and development of $B$. mori have been accorded importance in sericultural research (Laskar and Datta, 2000; Kanafi et al., 2007). Such studies largely focused on the enrichment of the silkworm diet (i.e., mulberry leaves) with exogenous nutrients such as proteins, carbohydrates, amino acids, vitamins, minerals, hormones, antibiotics and assessing their influence on desired parameters of B.mori (Sanappa et al., 2002; Bhattacharya and Kaliwal, 2004, 2005a, 2005b, 2005c; Chakrabarty and Kaliwal, 2011; Kavitha et al., 2012; Thulasi and Sivaprasad, 2013, 2014).

The honey is a natural sweetener and multi- factorial nutrient produced by the honey bees from the floral nectar (Council of European Union, 2002). It is a rich nutrient and includes a variety of sugars, proteins, enzymes, vitamins and minerals and its chemical composition and characteristics vary depending on its geographical, environmental and botanical origin (Ramirez, 2000; Falco et al., 2003; Anonymous, 2003; Garcia et al., 2005; David Ball, 2007). Further, the honey is an insect product and possess valuable nourishing, healing and prophylactic properties and used as an ingredient of human and veterinary medicines (Taormina, 2001; Cooper et al., 2002; Anonymous, 2003; Eileen De Mars, 2003; Iglesias et al., 2004). Most of the enrichment studies employed commercial and expensive nutrients, but, no effort has since been made to examine the impact of an insect product and all-in-one nutrient like honey on the silkworm growth, metabolism and economic traits of sericulture.

Keeping in view the high nutritional and medicinal status of honey, the present study explores the possibility of including honey in the silkworm diet by analyzing its impact on the larval growth and protein profiles of B. mori and on the economic parameters of sericulture.

\section{MATERIALS AND METHODS}

The present investigation was carried out on PM $\mathrm{x}$ $\mathrm{CSR}_{2}$ hybrid variety of the silkworm (Bombyx mori), reared under standard environmental conditions of $28^{0} \mathrm{C}, 85 \% \mathrm{RH}$ as per Krishnaswami (1986). After hatching, the worms were reared on $\mathrm{M}_{5}$ variety of mulberry leaves by giving 5 feeds per day at $6 \mathrm{AM}, 10$ AM, 2 PM, 6 PM and 10 PM, under normal $12 \mathrm{hrs}$ light and 12 hrs dark conditions. The experimental design was divided into four phases, namely honey feeding pattern, study of growth patterns, assay of tissue proteins and analysis of economic parameters of 


\section{sericulture.}

Honey feeding pattern: After the third moult, the fourth instars larvae were divided into five batches of 100 worms each. One was treated as the control batch and four others as experimental batches. The control batch was fed with normal feedings 5 times a day as stated earlier and the experimental batches were fed with mulberry leaves soaked in $2 \%$ honey in distilled water, the minimum effective concentration of which has been determined earlier by us (Sivaprasad and Thulasi, 2014). Before feeding, the wet mulberry leaves were dried under cool weather conditions. While the honey-enriched leaves were fed to the silkworms at $6 \mathrm{PM}$, normal feeding pattern was continued at other timings during the day.

Silkworm growth: Studies under this head included the impact analysis of honey on the growth of the larval body and silk gland (SG) during fifth in star development. The growth of both the larval body and SG was ascertained in both control and experimental batches and the latter included a single treatment condition i.e.; the larvae fed with fortified mulberry leaves with $2 \%$ minimum effective concentration of honey. The body and SG weights were measured in an electronic balance (ELICO; Model BL- $22 \mathrm{OH}$ ) on alternative days of fifth instar (i.e.; day1, day-3, day-5 and day-7). The mean weight of 25 randomly selected larvae and 5 pairs of silk glands were taken as the standard weights and the same were expressed in grams.

Assay of tissue proteins: Total protein levels of the silk land (SG), fat body (FB) and haemolymph (HL) were analyzed on day-1, day-4 and day-7 during fifth instar larval development. While the SG and FB were isolated by mid- dorsal dissection of larval body in the Silkworm Ringer (Yamaoka et al., 1971), the HL was extracted by cutting the telson and pro-legs. The total protein content was estimated in $1 \%$ homogenates of SG and FB and 1:9 diluted HL (1:9 haemolymph and distilled water) by the method of Lowry et al. (1951) and the same was expressed in mg protein / gram wet weight of tissue (or) $\mathrm{mg} / \mathrm{ml}$ of haemolymph. Similarly, the protein content of the cocoon was estimated in $1 \%$ homogenate in distilled water. Since the silk cocoon is not soluble in distilled water, it was first soaked in diluted sodium hydroxide solution before homogenized in distilled water.

Analysis of economic parameters: Nine important economic parameters of sericulture, viz., as the green cocoon weight, shell weight, shell protein, floss weight, floss protein, pupal weight, raw silk weight, denier, renditta, were analyzed as per the methods given by Bohidar et al., 2007; Rahmathulla et al., 2007; Sailaja and Sivaprasad, 2010).

Statistical analysis: The data were analyzed by statistical tools such as mean, standard deviation (SD), Percent change and test of significance. While the mean and SD were computed using M.S. Excel, the test of Significance and percent -changes was calculated by online using the Graph pad and percent change platforms (www. Graph pad. Com/quick calcs/index cfm/and www. Percent-change com/ index php). Further, in order to draw meaningful conclusions, the growth trends in larval body, SG and silk gland proteins were interpreted in terms of an innovative statistical parameter called compound periodical growth rate (CPGR) as given by Sivaprasad (2012).

\section{RESULTS}

The findings of the present investigation on the larval growth, silk gland growth and protein profiles and economic traits profiles of sericulture are presented in Tables 1 to 3 and in Figs. 1 to 3 .

Body versus gland growth: Under natural conditions, the larval weight of the control batch grew maximally by $\sim 128 \%$ on day-3, $\sim 67 \%$ on day- 5 and minimally by $\sim 15 \%$ on day- 7 with an overall increase of $334 \%$ and a CPGR of $63.18 \%$ (Table 1, Fig. 1). At the same time, the SG grew maximally by $\sim 411 \%$ on day $-3, \sim 98 \%$ on day-5 and $\sim 92 \%$ on day-7, representing an overall increase of $\sim 1844 \%$ during fifth instar with a CPGR of $227.11 \%$ (Table 1). The computed gland- body ratio showed an increase of $\sim 125 \%$ on day-3, $\sim 19 \%$ on day-5 and $\sim 92 \%$ on day- 7 with an overall increase of $334 \%$ and a CPGR of $\sim 64.82 \%$ in the control batch. Under the influence of $2 \%$, minimum effective concentration of honey, the larval body weight recorded an increase of $\sim 155 \%$ on day-3, $\sim 58 \%$ on day-5 and $\sim 18 \%$ on day- 7 with an overall increase of $374 \%$ and a CPGR of $\sim 68 \%$ during fifth instar larval development (Table 1 ). At the same time, the SG grew by $\sim 483 \%$ on day-3, $\sim 167 \%$ on day-5 and $\sim 53 \%$ on day- 7 , with an overall increase of $2289 \%$ and a CPGR of $250.34 \%$. The gland- body ratio recorded an increase of $\sim 129 \%$ on day-3, $\sim 69 \%$ on day-5 and $\sim 31 \%$ on day-7, representing an overall growth of $\sim 404 \%$, and a CPGR of $\sim 71.47 \%$ (Table 1, Fig. 1).

Silk gland proteins (SGP): Since the honey caused significant improvement in the whole SGP, it is necessary to find as to which region of SG responds more effectively to this exogenous factor. Hence, protein levels were estimated separately in the three regions namely, anterior silk gland (ASG), middle silk gland (MSG) and posterior silk gland (PSG) and the relevant data are presented in table 2 and fig. 2. The protein profiles of ASG in the control and honey treated batch were elevated respectively by $\sim 16 \%$ and $51 \%$ on day-3, $3 \%$ and $31 \%$ on day-5 and just by $17 \%$ and $16 \%$ on day- 7 . In the MSG, the corresponding elevations were $\sim 44 \%$ and $101 \%$ on day-3, $45 \%$ and $9 \%$ on day-5 and $\sim 51 \%$ and $69 \%$ on day- 7 . While those in PSG were $\sim 41 \%$ and $103 \%$ on day-3, $\sim 21 \%$ and $6 \%$ on day-5 and $\sim 51 \%$ and $64 \%$ on day-7. During the entire period of fifth instar, the overall growth trends in the total protein levels of control and experimental batches were $\sim 39 \%$ and $102 \%$ in $\mathrm{ASG}, \sim 213 \%$ and $\sim 272 \%$ in MSG and $\sim 158 \%$ and $254 \%$ in PSG. Similarly, the corresponding CPGRs were $11.64 \%$ and $26.49 \%$ in $\mathrm{ASG}, \sim 46.25 \%$ 
Table 1. Effect of $2 \%$ honey on body weight (BW), silk gland (SG) weight and gland- body ratio (GBR) in B. mori, during fifth instar larval development.

\begin{tabular}{|c|c|c|c|c|c|c|c|}
\hline \multirow[t]{2}{*}{ Day } & \multirow{2}{*}{$\begin{array}{c}\text { Statistical } \\
\text { tool }\end{array}$} & \multicolumn{3}{|c|}{ Control } & \multicolumn{3}{|c|}{ Experimental (2\% Honey) } \\
\hline & & BW (g) & SG weight (g) & GBR & BW (g) & SG weight (g) & GBR \\
\hline \multirow[b]{2}{*}{1} & Mean & 0.58 & 0.018 & 3.10 & 0.58 & 0.018 & 3.10 \\
\hline & S.D & \pm 0.008 & \pm 0.0009 & \pm 0.009 & \pm 0.008 & \pm 0.0009 & \pm 0.009 \\
\hline \multirow{3}{*}{3} & Mean & 1.32 & 0.092 & 6.96 & 1.48 & 0.105 & 7.09 \\
\hline & P.C & $(127.58)$ & $(411.11)$ & $(124.51)$ & $(155.17)$ & $(483.33)$ & $(128.70)$ \\
\hline & S.D & $\pm 0.02 *$ & $\pm 0.001 *$ & $\pm 0.008 *$ & $\pm 0.01 *$ & $\pm 0.002 *$ & $\pm 0.008 *$ \\
\hline \multirow{3}{*}{5} & Mean & 2.20 & 0.182 & 8.27 & 2.34 & 0.280 & 11.96 \\
\hline & P.C & $(66.66)$ & $(97.82)$ & $(18.82)$ & $(58.10)$ & $(166.66)$ & $(68.68)$ \\
\hline & S.D & $\pm 0.01^{*}$ & $\pm 0.001 *$ & $\pm 0.009^{*}$ & $\pm 0.01^{*}$ & $\pm 0.0009 *$ & $\pm 0.01 *$ \\
\hline \multirow{3}{*}{7} & Mean & 2.52 & 0.350 & 13.88 & 2.75 & 0.43 & 15.63 \\
\hline & P.C & (14.54) & $(92.30)$ & $(67.83)$ & $(17.52)$ & $(53.57)$ & $(30.68)$ \\
\hline & S.D & $\pm 0.009 *$ & $\pm 0.009 *$ & $\pm 0.02 *$ & $\pm 0.008 *$ & $\pm 0.01 *$ & $\pm 0.01 *$ \\
\hline \multicolumn{2}{|c|}{ OPC (\%) } & 334.5 & 1844.4 & 347.7 & 374.1 & 2288.9 & 404.2 \\
\hline \multicolumn{2}{|c|}{ CPGR (\%) } & 63.18 & 227.11 & 64.82 & 68.0 & 250.34 & 71.47 \\
\hline
\end{tabular}

* Statistically significant $(\mathrm{P}$ value $<0.001)$ : **Statistically not significant. Each value is a mean, \pm standard deviation of four individual observations. The percent changes were calculated taking the previous value as the base value, while the overall percentages (OPCs) and the compound periodical growth rates (CPGRs) were computed on the basis of first and seventh day values as per Sivaprasad, 2012.

Table 2. Effect of $2 \%$ honey on the total protein profiles $(\mathrm{mg} / \mathrm{g})$ of different regions of the silk gland in the fifth instar larva of B. mori.

\begin{tabular}{|c|c|c|c|c|c|c|c|}
\hline \multirow{2}{*}{ Day } & \multirow[b]{2}{*}{$\begin{array}{c}\text { Statistical } \\
\text { tools }\end{array}$} & \multicolumn{2}{|c|}{ ASG } & \multicolumn{2}{|c|}{ MSG } & \multicolumn{2}{|c|}{$\begin{array}{l}\text { PSG } \\
\end{array}$} \\
\hline & & Control & $\begin{array}{c}\text { Experimental } \\
\text { (2\% Honey) }\end{array}$ & Control & $\begin{array}{c}\text { Experimental } \\
(2 \% H o n e y)\end{array}$ & Control & $\begin{array}{c}\text { Experimental } \\
(2 \% \text { Honey })\end{array}$ \\
\hline \multirow[t]{2}{*}{1} & Mean & 10.88 & 10.88 & 20.18 & 20.18 & 19.04 & 19.04 \\
\hline & S.D & \pm 0.83 & \pm 0.83 & \pm 0.36 & \pm 0.36 & \pm 0.45 & \pm 0.45 \\
\hline \multirow[t]{3}{*}{3} & Mean & 12.63 & 14.56 & 28.97 & 40.63 & 26.88 & 38.64 \\
\hline & P.C & $(16.08)$ & $(50.76)$ & $(43.55)$ & (101.33) & $(41.17)$ & $(102.94)$ \\
\hline & S.D & $\pm 0.009 *$ & $\pm 0.01 *$ & $\pm 0.49 *$ & $\pm 1.47 *$ & $\pm 0.008^{*}$ & $\pm 0.70^{*}$ \\
\hline \multirow[t]{3}{*}{5} & Mean & 12.98 & 19.02 & 41.88 & 44.27 & 32.64 & 41.03 \\
\hline & P.C & $(2.77)$ & $(30.63)$ & $(44.56)$ & $(8.95)$ & $(21.42)$ & $(6.18)$ \\
\hline & S.D & $\pm 0.008 *$ & $\pm 0.01^{*}$ & $\pm 0.45^{*}$ & $\pm 1.08^{*}$ & $\pm 0.01 *$ & $\pm 0.90 *$ \\
\hline \multirow[t]{3}{*}{7} & Mean & 15.14 & 22.02 & 63.13 & 75.05 & 49.21 & 67.40 \\
\hline & P.C & (16.64) & $(15.77)$ & $(50.74)$ & $(69.52)$ & $(50.76)$ & $(64.27)$ \\
\hline & S.D & $\pm 0.20^{*}$ & $\pm 0.14^{*}$ & $\pm 0.22 *$ & $\pm 0.55^{*}$ & $\pm 0.02 *$ & $\pm 0.64 *$ \\
\hline \multicolumn{2}{|c|}{ OPC (\%) } & 39.2 & 102.4 & 212.8 & 271.9 & 158.5 & 254.0 \\
\hline \multicolumn{2}{|c|}{ CPGR (\%) } & 11.64 & 26.49 & 46.25 & 54.93 & 37.23 & 52.40 \\
\hline
\end{tabular}

* Statistically significant $(\mathrm{P}$ value $<0.001): * *$ Statistically not significant; Each value, expressed in $\mathrm{mg} / \mathrm{g}$ wet weight of tissue, is a mean, \pm standard deviation of four individual observations. The percent changes were calculated taking the previous value as the base value, while the overall percentages (OPCs) and the compound periodical growth rates (CPGRs) were computed on the basis of first and seventh day values as per Sivaprasad, 2012. ASG: Anterior silk gland; MSG: Middle silk gland; PSG: Posterior silk gland

and $54.93 \%$ in MSG and $37.23 \%$ and $52.40 \%$ in PSG (Table 2, Fig. 2).

Economic traits: The positive impact of $2 \%$ honey has been extended to the economic parameters of sericulture such as the green cocoon weight, shell weight, shell protein, floss weight, floss protein, pupal weight, raw silk weight, denier and renditta (Table 3, Fig. 3). The impact yielded significant gains in profitable traits and reductions in loss making ones. Under its influence, the green cocoon weight increased by $\sim 23 \%$, shell weight by $\sim 118 \%$, shell protein by $\sim 18 \%$, pupal weight by $\sim 13 \%$, raw silk weight by $\sim 18 \%$ and denier by $\sim 18 \%$. The positive impact of honey is further reinforced by reduction in floss weight by $\sim 13 \%$ and floss protein by $\sim 25 \%$ and renditta by $\sim 2 \%$ (Table 3 ). Further, the raw silk generated from the experimental stock has 
Table. 3. Effect of $2 \%$ honey on the economic traits of B. mori.

\begin{tabular}{|c|c|c|c|c|}
\hline S. $\mathbf{N}$. & Parameters & Statistical tools & Control & Honey treated \\
\hline 1 & Green cocoon Weight $(\mathrm{g})$ & $\begin{array}{c}\text { Mean } \\
\text { P.C } \\
\text { S.D }\end{array}$ & $\begin{array}{c}0.96 \\
- \\
\pm 0.02\end{array}$ & $\begin{array}{c}1.08 \\
(22.91) \\
\pm 0.0009^{*}\end{array}$ \\
\hline 2 & Shell Weight (g) & $\begin{array}{l}\text { Mean } \\
\text { P.C } \\
\text { S.D }\end{array}$ & $\begin{array}{c}0.17 \\
- \\
\pm 0.009\end{array}$ & $\begin{array}{c}0.37 \\
(117.64) \\
\pm 0.01 *\end{array}$ \\
\hline 3 & Shell protein $(\mathrm{mg} / \mathrm{g})$ & $\begin{array}{l}\text { Mean } \\
\text { P.C } \\
\text { S.D }\end{array}$ & $\begin{array}{c}36.01 \\
- \\
1.01\end{array}$ & $\begin{array}{c}42.6 \\
18.30 \\
\pm 0.14^{*}\end{array}$ \\
\hline 4 & Floss Weight (g) & $\begin{array}{l}\text { Mean } \\
\text { P.C } \\
\text { S.D }\end{array}$ & $\begin{array}{c}0.024 \\
- \\
\pm 0.004\end{array}$ & $\begin{array}{c}0.021 \\
(-12.5) \\
\pm 0.003 * *\end{array}$ \\
\hline 5 & Floss protein (mg/g) & $\begin{array}{l}\text { Mean } \\
\text { P.C } \\
\text { S.D }\end{array}$ & $\begin{array}{c}7.27 \\
- \\
0.17\end{array}$ & $\begin{array}{c}5.42 \\
(-25.44) \\
\pm 0.03 *\end{array}$ \\
\hline 6 & Pupal weight (g) & $\begin{array}{l}\text { Mean } \\
\text { P.C } \\
\text { S.D }\end{array}$ & $\begin{array}{c}0.92 \\
- \\
\pm 0.003\end{array}$ & $\begin{array}{c}1.04 \\
(13.04) \\
\pm 0.003 *\end{array}$ \\
\hline 7 & Raw silk weight (g) & $\begin{array}{l}\text { Mean } \\
\text { P.C } \\
\text { S.D }\end{array}$ & $\begin{array}{c}14.87 \\
- \\
\pm 0.01\end{array}$ & $\begin{array}{c}17.48 \\
(17.55) \\
\pm 0.01 *\end{array}$ \\
\hline 8 & Denier & $\begin{array}{l}\text { Mean } \\
\text { P.C } \\
\text { S.D }\end{array}$ & $\begin{array}{c}11.85 \\
- \\
\pm 0.008\end{array}$ & $\begin{array}{c}13.93 \\
(17.55) \\
\pm 0.07^{*}\end{array}$ \\
\hline 9 & Renditta & $\begin{array}{c}\text { Mean } \\
\text { P.C } \\
\text { S.D }\end{array}$ & $\begin{array}{c}5.20 \\
- \\
\pm 0.01\end{array}$ & $\begin{array}{c}5.07 \\
(-2.5) \\
\pm 0.01 *\end{array}$ \\
\hline
\end{tabular}

*Statistically significant $(P$ value $<0.001)$ : **Statistically not significant. Each value is a mean \pm standard deviation of four individual observations. The weights of the cocoon, shell and floss represent the mean of 25 individual cocoons, expressed in grams. The values in parentheses represent the percent changes from the control.

light yellow colour compared to the control stock which bear dark yellow colour (Fig. 3).

\section{DISCUSSION}

Honey is the richest and natural nutrient comprising chiefly carbohydrates (82\%) that meet the energy requirements of metabolism and silk production. It also includes proteins, enzymes (e.g. Diastase, invertase, glucose oxidase, catalase, etc.), free amino acids, trace amounts of $\mathrm{B}$-vitamins and vitamin $\mathrm{C}$, and metals such as $\mathrm{Cr}, \mathrm{Co}, \mathrm{Cu}, \mathrm{Fe}, \mathrm{Mn}$ and $\mathrm{Zn}$ (Falco et al., 2003; Garcia et al., 2005; David Ball, 2007). Due to high nutritive value, it plays a vital role on the growth and metabolism of organism, a fact that has been clearly demonstrated in B. mori in its larval growth, protein profiles and economic traits of sericulture.

Honey versus Larval growth: In the control batch, the larval growth recorded a CPGR of $\sim 25.28 \%$ in fifth instar. The larvae fed with $2 \%$ honey enriched mulberry leaves the growth was elevated by $\sim 30.03 \%$ in fifth instar. Thus, honey positively reinforced the day-today larval growth rates by 4.75 percentile points ( 30.03 - 25.28) in fifth instar. Another noteworthy feature of silkworm development is that the larvae grow exponentially in early phases of instar and slowly at later phases (Table 1).

Honey versus gland-body ratio: The determination of gland- body ratio (GBR) by comparatively analyzing the changes in the weights of the larval body and silk gland during fifth instar development is considered as valuable indicator of silk production (Sailaja and Sivaprasad, 2010). Higher GBR could be achieved by enriching mulberry leaves with potential exogenous modulators and nutrients. The honey is identified as one such modulator. As shown in table 1, this exogenous factor has shown profound effect on GBR in B. mori. The data analyzed in terms of CPGR and overall percent change (OPC) clearly demonstrates the positive impact of honey on silkworm. Under the influence of $2 \%$ honey, the CPGR of body weight grew by 4.82 percentile points (68.0 - 63.18) while OPC of the SG weight grew 


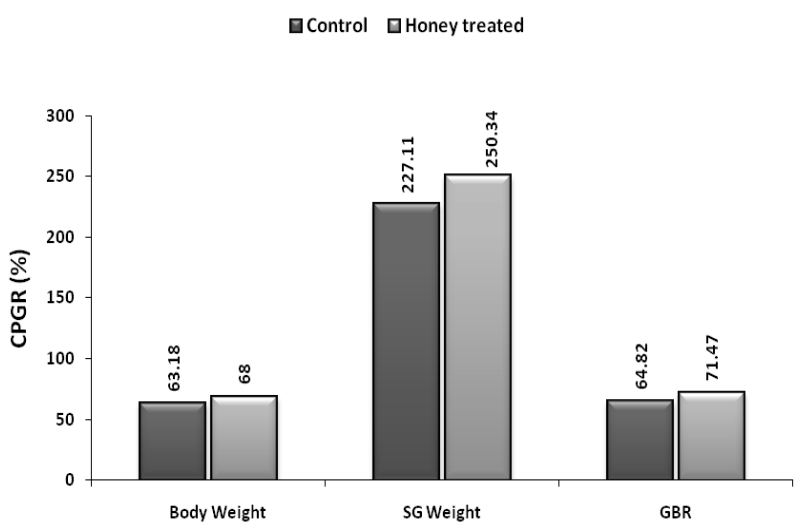

Fig. 1. Effect of honey on the silk gland-body ratio during fifth instar larval development in the silkworm, B. mori. The values, expressed in percentages, represent the compound periodical growth rates (CPGRs), computed on the basis of initial (Day-1) and final (Day-7) values of fifth instar.

by 4.45 additional percentile points $(2289-1844)$. At the same time the GBR grew by 6.64 percentile points (71.47-64.82) in terms of CPGR and by 56.45 percentile points (404.19-347.74) in terms of OPC (Fig.1). As reported earlier, the impact of honey on larval growth is attributable to its constituent vitamins and minerals (Bhattacharya and Kaliwal, 2005a, 2005b; Rajabi et al., 2006a; Kavitha et al., 2012).

Honey versus silk proteins: The SGP pool includes two silk proteins (Fibroin and sericin) and 91 other proteins involved in metabolism, immunity, heat-shock mechanism, cytoskeleton formation, protease inhibition transport and transcription (Nirmala et al., 2001; Jin et al., 2004; Takasu et al., 2005; Kyung et al., 2006; Zhang et al., 2006; Hou et al., 2007). Under the impact of $2 \%$ honey, the SGP profiles grew by 33.08 percentile points (144.86 - 111.78) during fifth instar development (Table 2, Fig. 2). Within the silk gland, ASG is relatively inert and shows low protein level, while MSG and PSG acts as protein reservoirs (Shimura, 1993). The study yielded interesting results and demonstrated that honey stimulates protein synthesis in all the three regions of silk gland but predominantly in ASG and PSG. The analysis of SGP in terms of overall percent changes (OPC) and compound periodical growth rates (CPGR) reveals this fact. The protein profiles of PSG grew maximally by 99.54 percentile points (OPC: 253.99154.54) during fifth instar development showing an additional daily growth of 15.17 percentile points (CPGR: 52.40-37.23). The protein profiles of ASG, which were very low in the control batch, grew moderately by 63.23 percentile points (OPC: 102.3839.15 ), with a daily growth rates of 14.85 additional percentile points (CPGR: 26.49-11.64) during fifth instar. At the same time the protein base of MSG grew by 59.07 percentile points (OPC: 271.90-212.83), with a daily average of 8.68 additional percentile points (CPGR: 54.93 - 46.25) (Table 2, Fig. 2). Needless to say, the higher protein gain in the three segments of

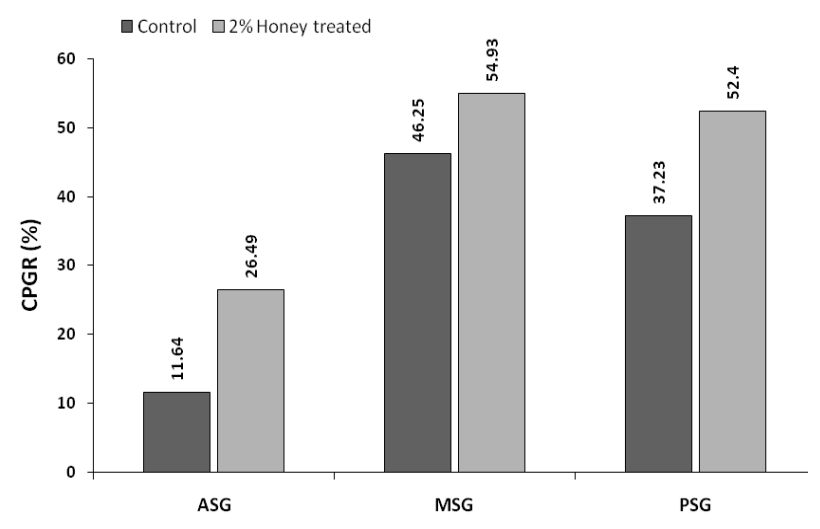

Fig. 2. Overall effect of $2 \%$ honey on the protein profiles in the different segments of the silk gland in Bombyx mori during fifth instar development. The values, expressed in percentages, represent compound periodical growth rates (CPGRs), computed on the basis of initial (Day-1) and final (Day-7) values of fifth instar.

silk gland is attributable to the high nutritional status of honey in terms of its vitamin and mineral profiles (Hussain and Javed, 2002; Etebari and Matindoost, 2005; Thilsath et al., 2008; Thulasi and Sivaprasad, 2013, 2014).

Honey versus economic parameters: The impact of honey on the economic parameters of sericulture is generally positive at its minimum effective concentration of $2 \%$ in distilled water. Its effectiveness is attributable to its stimulatory role on growth and silk protein synthesis during larval and pupal stages. Evidently, the positive impact of honey on the larval growth, observed during active fourth $(\sim 13 \%)$ and fifth instar $(\sim 25 \%)$ stages, has been extended to the quiescent pupal stage with $13.04 \%$ improvement in body weight and its 34\% elevation in silk protein synthesis (Table 3). The profitable impact of honey on economic traits appears to be achieved by its two-fold impact on protein synthesis. Firstly, it acts as a potential stimulator of protein synthesis in all the three segments (ASG, MSG and PSG) of the silk gland. Secondly, its stimulatory effect is more specific on shell protein (Fibroin) compared to floss protein (Sericin). Probably, because of this reason, the shell protein levels recorded an increase of over $18 \%$ and the same was accompanied by a reduction in the levels of floss protein by $\sim 25 \%$, under the impact of honey. This dual effect in turn caused a rise in the raw silk weight and denier (thickness of silk fibre) by $18 \%$ each and a reduction in the renditta (the number of kilograms of cocoons required for production of $1 \mathrm{~kg}$ of raw silk) by $2.5 \%$ (Table 3 , Fig.3).

The major impact of honey on SG seems to enhance silk protein synthesis both in qualitative and quantitative terms, leading to improvement in the cocoon economic parameters. More importantly, the prevalence of higher protein levels in the MSG, indicates that silk gland proteins are predominantly synthesized in this region of silk gland. A comparative analysis of SGP vis-à-vis 


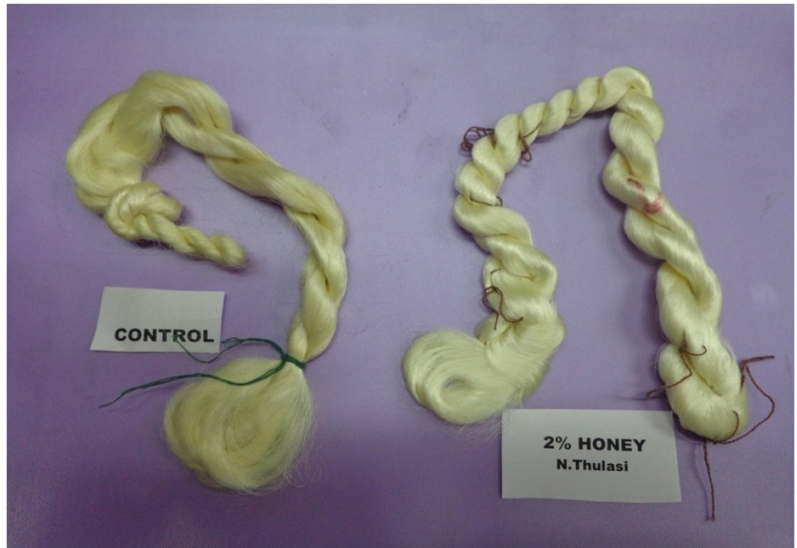

Fig.3. Raw silk reeled from 100 green cocoons produced by $B$. mori in the control and honey treated conditions. Note significant increase in the output of raw silk and its colour under treatment conditions

economic parameters indicates that the honey modulates the tissue protein profiles in the silkworm, either by de novo synthesis or by sequestration from other tissues. Both these mechanisms are likely in B. mori.

\section{Conclusion}

Honey is a potent modulator of growth, metabolism and silk production in Bombyx mori. Its potential could be realized at the minimum effective concentration of $2 \%$ in distilled water. For improvements in the economic parameters of sericulture, the application of $2 \%$ honey-enriched mulberry diet is recommended for silkworms. At this concentration, the honey not only stimulates silk protein synthesis in the silk gland, but also mobilizes appropriate protein reserves from fat body and fine tunes the silk output. In doing so, the honey confers two-fold advantage on sericultrists. Firstly, it enhances silk productivity and quality and secondly, it reduces floss output which is treated as the sericultural wastage. However, extensive field trials are recommended before its application in sericulture.

\section{ACKNOWLEDGEMENT}

Authors thank the University Grants Commission, New Delhi for providing financial assistance in the form of Rajiv Gandhi National Fellowship for this research work.

\section{REFERENCES}

Annonymous (2003). Honey Research: Honey- Health and Therapeutic Qualities. The National Honey Board. Retrieved May, 152014 from http://www. Nhb.org/ down-load/ factsht/ Compendium.Pdf.

Bhattacharya, A. and Kaliwal, B.B. (2004). Influence of mineral potassium permanganate on the biochemical constituents in the fat body and haemolymph of the silkworm, B. mori L. Int. J. Indust. Entomol., 9 (1): 131135.

Bhattacharya, A. and Kaliwal, B.B. (2005a). The biochemical effects of potassium chloride on the silkworm, Bombyx mori L. Insect. Science, 12:95-100

Bhattacharya, A. and Kaliwal, B.B. (2005b). Synergetic effects of potassium and magnesium chloride on biochemical contents of the silkworm, Bombyx mori L. Caspian. J. Env. Sci., 3(1): 1-7.

Bhattacharya, A. and Kaliwal, B.B. (2005c). Fortification of mulberry leaves with mineral

Magnesium chloride $\left(\mathrm{MgCl}_{2}\right)$ on Biochemical contents of the silkworm, Bombyx mori L. The Philippine Agricultural Scientist, 38(3): 337-340.

Bohidar, K., Sahoo, B.S. and Singh, D.K. (2007).Effect of different varieties of mulberry leaves on economic parameters of the silkworm Bombyx mori L. under Orissa climate. Bull. Ind. Acad. Seric., 11: 60-64.

Chakrabarty, S. and Kaliwal, B.B. (2011). Supplementation with Potassium carbonate, magnesium carbonate and their synergetic effects on the economic traits of the silkworm, Bombyx mori L. World Journal of Science and Technology, 1 (5): 10-23.

Cooper, R.A., Molan P.C. and Harding, K.G (2002). The sensitivity to honey of gram- positive cocci of clinical significance isolated from wounds. J. Appl. Microbiol., 93 (5): 857-863.

Council of European Union (2002). Council Directive 2001/110/Ec of 20 December 2001 relating to honey. Offic. J. the. Europ. Comm., LIO.47-52.

David Ball, W. (2007).The Chemical composition of honey. Chem. Educ., 84 (10): p. 1643.

Eileen De Mars (2003).The importance of honey. National Honey Board.No. 650: 123- 135.

Etebari, K. and Matindoost, L. (2005). Application of multivitamins as nutrients on biological and economical characteristics of silkworm Bombyx mori L. J. AsiaPacific Entomol., 8:1-6.

Falco, G., Gomez-Catalan, C., Llobet, J.M. and Domingo, J.L. (2003). Contribution of medicinal plants to the dietary intake of various toxic elements in Catalonia, Spain. Trace Elem. Electrolyte, 20: 120-124.

Garcia, J.C.R., Garcia, J.B., Latorre, C.H., Martin, S.G. and Crecent, R.M.P. (2005). Comparison of Palladiummagnesium nitrate and ammonium di hydrogen phosphate modifiers for lead determination in honey by electro thermal atomic absorption modifiers spectrometry. Food Chem., 91: 435-439.

Hou, Y., Xia, Q., Zhao, P., Zou, Y., Liu, H., Guan, J., Gong, J. and Xiang, Z. (2007). Studies on middle and posterior silk glands of silkworm (Bombyx mori) using two-dimensional electrophoresis and mass spectrometry. Insect Biochem. Mol. Biol.,37:486-496.

Hussain, M. and Javed, H. (2002). Effect of $0.2 \%$ of $\mathrm{N}$ with various combination of ascorbic acid on growth and silk production of silkworm Bombyx mori L. Asian J. Plant Sci., 1: 650-651.

Iglesias, M.T., De Lorenzo, C., Polo, M. D-C., Martin- Avarez and Pueyo, E. (2004). Usefulness honey dew and floral honey. Application to honeys from a small geographic area. J. Agric. Food. Chem., 52: 84-89.

Jin, Y.X., Chen, Y.Y., Xu, M.K. and Y.H. Jiang (2004). Studies on middle silk gland portions of cocoon colour sex-limited silkworm (Bombyx mori) using two dimensional polyacrylamide gel electrophoresis. J. BioSci.,29:45-49.

Kanafi, R.R., Ebadi, R., Mirhosseini, S.Z., Seindavi, AR., Zolfaghari, M. and Eteban, K. (2007). A review on nutritive effect of mulberry leaves enrichment with 
vitamins on economic parameters traits and biological parameters of silkworm, Bombyx mori L. Indian Sericulture Journal, 4: 86-91.

Kavitha, S., Sivaprasad, S., Bano Saidulla and Yellamma, K. (2012). Effect of zinc chloride and zinc sulphate on the silkworm, Bombyx mori growth, tissue proteins and economic parameters of sericulture. The Bioscan, 7 (2):189-195.

Krishnaswami, S. (1986). New Technology of silkworm rearing. Central Sericultural Research and Training Institute, Mysore, India.

Kyung, H.S., Su, J.J., Yong, R.S., Seok, W.K. and Sung, S.H. (2006). Identification of up-regulated proteins in the haemolymph of immunized. Bombyx mori larvae. Comp. Biochem. Physiol., Dl: 260-266.

Laskar, N. and Datta, M. (2000). Effect of alfalfa tonic and its organic in gradients on growth and development of silkworm Bombyx mori L. race instar. Environ. Ecol., 18:591-596.

Lowry, O.H., Rosenbrough, N.J., Farra, L. and Randall, R.J. (1951). Protein measurement with folin phenol reagent. J. Biol. Chem.,33:19-27.

Nirmala, X., Mitta, K., Vanisree, V., Zurovec, M. and Sehnal, F. (2001). Identification of four small molecular mass proteins in the silk of Bombyx mori. Insect Mol., 10: 437-445.

Rahmathulla, V.K., Priyabrata Das, Ramesh, M. and Rajan, R.K. (2007). Growth rate pattern and economic traits of silkworm, Bombyx mori, L. under the influence of folic acid administration. J. Appl. Sci.Environ.Manage.,11: 81-84.

Rajabi, R., Ebadi, R., Fazilati, M., and Mirhoseini, S.Z. (2006a). Nutritive effects of mulberry leaves enrichment with riboflavin vitamin on bio-economic characters of silkworm, Bombyx mori L. $9^{\text {th }}$ Arab Congress of plant Protection, 19-23, November, Damascus, Syria.

Ramirez, C.M.A., Gonzales Novel, S.A. and Sauri Duch, E. (2000).Effect of the temporary thermic treatment of honey on variation of the quality of the same during storage. Apiacta, 35: 162-170.

Sailaja, B. and Sivaprasad, S. (2010). Photoperiodic modulation of circadian rhythms in the silk gland protein profiles of Bombyx mori and its influence on the silk productivity and quality. J. Appl. \& Nat. Sci., 2: 48-56.
Sanappa, B., Ramaiah, M. J. and Chandrappa, D. (2002). Influence of castor genotype on consumption indices of eri silkworm sumia Cynthia ricini. Bioduval. Environ. Ecol., 20: 960-964.

Sivaprasad, S. (2012). Simple method for calculation periodical growth rates in animals and plants. J. Bio. Innov., (5):114-119.

Sivaprasad, S. and Thulasi, N.(2014). Determination of minimum effective concentration of honey for optimal growth, metabolism and silk production in the silkworm, Bombyx mori. Ind. J.Appl. Res., 4 (12): 542-545.

Shimura, K. (1993). Physiology and biology of spinning in Bombyx mori. Experientia ,39: 44-450.

Takasu, Y., Yamada, H., Saito, H. and Tsubouchi, K. (2005). Characterization of Bombyx mori sericins by the partial amino acid sequences. J. Insect Biotechnology and Sericology, 74:103-109.

Taormina, P. J., Niemira, A. B. and Beuchat, L.R. (2001). Inhibitory activity of honey against food borne pathogens as influenced by the presence of hydrogen peroxide and level of antioxidant power. Int. J. Food Microbiology, 69 (3): 217-225.

Thilsath Fathima Quraiza, M., Raja Rathi, C., Tamil Muthu, P., Sam Manohar Das, S. and Ramani Bai, M. (2008). A study on the effect of ascorbic acid in modifying tissue protein content and economic traits of Bombyx mori. L. Journal of Basic and Applied Biology, 2 (3\&4): 32-35.

Thulasi, N. and Sivaprasad, S. (2013). Synergetic effect of ascorbic acid and lemon juice on the growth and protein synthesis in the silkworm, Bombyx mori and its influence on economic traits of sericulture. J. Bio. Innov., 2(4): 168-183.

Thulasi, N. and Sivaprasad, S. (2014). Impact of feeding of lemon juice- enriched mulberry leaves on the larval growth, protein profiles and economic traits in the silk worm, Bombyx mori. Ind. J. Appl. Res., 4 (2):36-44.

Yamaoka, K., Hoshino, M. and Hirai, T. (1971). Role of sensory hairs on the anal papillae inoviposition behaviour of Bombyx mori. L. J. Insect Physiol., 47: 2327-2336.

Zhang, P.B., Aso, Y.K., Yamamoto, B.Y., Wang, Y.Q., Tsuchida, K.Y., Kawagnchi, H. and Fujii.(2006). Proteome analysis of silk gland proteins from the silkworm, Bombyx mori. Proteomics, 6:2586-2599. 